\title{
PEDAGOGY
}

\section{PRINCIPLES OF FORMING INTERCULTURAL EDUCATION IN THE EUROPEAN REGULATIONS AND AGREEMENTS}

\author{
Candidate of Pedagogical Sciences, Associate Professor Pryshlyak Oksana \\ Ukraine, Ternopil Volodymyr Hnatiuk National Pedagogical University
}

DOI: https://doi.org/10.31435/rsglobal_wos/31102019/6743

\section{ARTICLE INFO}

Received: 20 August 2019

Accepted: 22 October 2019

Published: 31 October 2019

\section{KEYWORDS}

intercultural education, intercultural competence, multicultural

education, European regulations and agreements, intercultural interaction, intercultural dialogue, multicultural environment. \begin{abstract}
In response to the challenges facing the world today the European countries, international organizations, associations, unions, numerous consultations are being held and numerous documents and recommendations are being adopted to seek and implement new approaches to foster intercultural dialogue. The author analyzed the basic principles of forming intercultural education in European regulations and agreements on understanding intercultural diversity and establishing intercultural dialogue. These documents play a leading role in the strategic planning of internal policy of the country to facilitate the formation of Ukraine as a multicultural country and to identify strategic aspects of shaping the intercultural education of specialists.
\end{abstract}

Citation: Pryshlyak Oksana. (2019) Principles of Forming Intercultural Education in the European Regulations and Agreements. International Academy Journal Web of Scholar. 10(40), doi: 10.31435/rsglobal_wos/31102019/6743

Copyright: (C) 2019 Pryshlyak Oksana. This is an open-access article distributed under the terms of the Creative Commons Attribution License (CC BY). The use, distribution or reproduction in other forums is permitted, provided the original author(s) or licensor are credited and that the original publication in this journal is cited, in accordance with accepted academic practice. No use, distribution or reproduction is permitted which does not comply with these terms.

Introduction. In the 21st century the vast majority of countries in the world have become multicultural. This process is driven by migration and integration processes, as well as the increasing mobility of students, workers in various fields and the increasing trend of migration of refugees from poor world regions. The countries today actively cooperate by creating relevant international and national regulations and agreements, and participate in programs, projects, in particular in the framework of international organizations.

An EU policy strategy has been proclaimed taking into account intercultural engagement both within the EU and internationally. That is why new strategic perspectives are being created to introduce the conceptual foundations of multicultural education and professional training of specialists to work in a multicultural environment, as a necessary condition for deepening European integration processes.

As Ukraine embarked on the path of European integration and trying to be an active player in the European political arena, it is therefore necessary to become familiar with policies on understanding intercultural diversity, governance, intercultural and multicultural education in Council of Europe documents, the European Union and other international organizations in response to the challenges of the modern world.

Short review of the publications on the subject. The principles of multicultural and intercultural education in European regulations and agreements were analyzed by Ukrainian scientists D. Kobzin, R. Sheiko, O. Martynenko, Yu. Belousov. Foreign researchers D. Faas, Ch. Hajisoteriou analyzed the political dimension of regulatory framework of intercultural education in Europe, M. Pečarević explored European cultural policy and intercultural dialogue, J. Tegovski analyzed the role of the Regional Cooperation Council in promoting intercultural dialogue in the South-East and P. Morris investigated 
legislation and policy in the context of Europe's religion and culture. Researcher I. Sikorskaya analyzed intercultural education policy and legislation in Europe in the context of cultural diversity.

Before joining the Council of Europe, Ukraine became a part of several conventions of the Organization, including the European Cultural Convention, the European Framework Convention on Transfrontier Co-operation between Territorial Communities or Authorities, and the Framework Convention for the Protection of National Minorities. Having acquired membership of the Council of Europe (November 9, 1995), Ukraine has undertaken a number of commitments to reform existing legislation based on the norms and standards of the Council of Europe.

The purpose of the article is to analyze European regulations and agreements to promote intercultural dialogue and ensure effective intercultural engagement, which form the conceptual framework for intercultural education and professional training for professionals in a multicultural environment.

Research results. The Council of Europe has consistently raised the question of fostering intercultural dialogue and fostering respect for cultural diversity [1]. The Council of Europe adopted "The European Cultural Convention" in 1954, which proclaimed the leading ideas of mutual understanding between the peoples of Europe and the mutual promotion of their cultural diversity; the protection of European culture; promoting national contribution to the common cultural heritage of Europe while respecting basic values, promoting language and history learning of European countries [2].

One of the leading European instruments on democracy, human rights, protection of national minorities and combating racism, anti-Semitism, xenophobia and intolerance was the "Vienna Declaration" (Council of Europe, 1993), signed by 32 member countries. The articles of the Vienna Declaration pointed to the leading directions of policy and education for the sake of peace and security of society. The Vienna Declaration defined the legal foundations of intercultural education: democracy, the rule of law, respect for human rights and national minorities, acceptance of cultural, ethnic and religious diversity [3].

One of the leading documents of the Council of Europe defining the principles for the implementation of education in multinational countries is the "Framework Convention for the Protection of National Minorities" (Council of Europe, 1995) [4], as well as the main principles for the formation of multiculturalism and the formation of a multicultural society developed by the "European Convention of Citizenship", which was adopted in 1997 and ratified by Ukraine ten years later (December 2007) [5].

Since the 2000s, the problem of cultural dialogue, intercultural interaction and intercultural and multicultural education has received new discussions at the UN, UNESCO, the Council of Europe at numerous conferences, working meetings. As a result, a number of important projects and international instruments on the development of cultural diversity, reducing the risk of discrimination of cultural minorities have been prepared and adopted. And this has contributed to the development of intercultural and multicultural education, the formation of intercultural competence as a significant factor and the precondition for the prosperity of the well-being of the multicultural world in general and in Europe in particular.

The Council of Europe initiated in 2000 an educational campaign "Europe is bigger than you think", within the framework of the campaign many actions were implemented under the general name "Response to a multicultural society". We consider it expedient to note that the actions had the conceptual position on the necessity of introducing different types and forms of intercultural education [6].

Analyzing the documents, we come to the position that Ukraine, as a member of the Council of Europe and the OSCE, has ratified a significant part of international instruments adopted by European legislators aimed at protecting vulnerable population (migrants, ethnic minorities) from acts of racism and xenophobia. These documents play a leading role in the strategic planning of the country's policy to facilitate the formation of Ukraine as a multicultural country and to identify strategic aspects of shaping the intercultural education of specialists.

In 2002 the Council of Europe adopted the document "The New Challenge of Intercultural Education: Religious Diversity and Dialogue in Europe", which addresses issues of intercultural education [7, p. 6].

An important Declaration was the "Intercultural education: managing diversity, strengthening democracy", adopted in November 2003 by the European Ministers of Education at a session in Athens (Council of Europe, 2003). The Declaration focused on the relationship between democracybuilding processes, the development of intercultural education and the role of these key components in reforming the European education system. It should be noted that the Declaration stated that intercultural education should become a permanent component of the educational policy of all European countries. This task can be accomplished through the proper development of curricula, introduction of intercultural education in the process of both general and vocational education and the appropriate training of specialists involved in the implementation of this process. 
We consider it necessary to add to the abovementioned documents, declaring the idea of implementing intercultural education of Council of Europe and European Union "The Declaration on 50 years of cultural cooperation in Europe", adopted by the Ministers for Culture, Education, Youth and Sport, signatories to the European Cultural Convention, Wroclaw (Poland), 10 December 2004 [8] and the "Declaration and Action Plan of the Third Summit of the Council of Europe" (Warsaw, 16-17 May 2005) (Warsaw Declaration)[9]. Based on the Declaration of the Third Summit the same year "Declaration on the Strategy for the Development of Intercultural Dialogue" (Faro Declaration) was adopted [10].

United Nations General Conference on Education, Science and Culture, at its 33rd session in Paris (October 2005), adopted the "Convention on the Protection and Promotion of the Diversity of Cultural Expressions". This document defines goals such as: promoting the diversity of cultural expressions; promotion of interculturalism for the development of interaction between cultures; promoting respect of cultural diversity and raising awareness of the value of this diversity at local, national and international levels [11].

The Commission of the EU and the European Parliament published a "Recommendation of the European Parliament and of the Council on Key Competences for Lifelong Learning" in 2006. Intercultural and civic competences have been defined as knowledge and skills that enable people to participate in increasingly diverse societies and to resolve conflicts where necessary. One of the eight competencies was identified as "Awareness and expression in the cultural sphere" [12].

The real condensation of the hard work of politicians, statesmen and public figures, experts from different countries, cultures, representatives of different religions and views has become the White Paper on Intercultural Dialogue "Living Together As Equals in Dignity", adopted by the 47 member states of the Council of Europe on May 7, 2008 at the 118th session of the Committee of Ministers of the Council of Europe. The White Paper argues that an intercultural approach will create a model for managing intercultural diversity, based on the dignity of the individual, and will embody a certain European identity, build on common fundamental values, respect for a common heritage and cultural diversity [13].

The White Paper considers the development of intercultural dialogue through the study and teaching of intercultural knowledge, and intercultural competence as the most important ability that each individual needs to develop in order to participate in intercultural dialogue. The White Paper states that Europe's support for an approach based on international law, the promotion of human rights, democracy and the rule of law should promote intercultural dialogue at the international level [14].

In 2011 the Council of Europe published a report "Living together. Combining diversity and freedom in 21 st-century Europe". The report stipulates the need to provide education for immigrant children, linking it with their further employment [15].

In the context of the formation of intercultural education, the resolution "Intercultural dialogue, cultural diversity and education" adopted by the EU in January 2016 is important. The document highlights the importance of teaching intercultural dialogue, learning intercultural competence, which is one of the leading tools for conflict prevention and management, building a sense of one's cultural identity. Teachers, parents and human rights organizations are key players in the process of intercultural education and intercultural learning. Undoubtedly, this political document has been developed and disseminated in order to give more political weight to issues of intercultural education as a leading conceptual approach to the organization of education in EU countries [16].

Particularly worth paying attention to Council of Europe document "Competences for Democratic Culture. Living together as equals in culturally diverse democratic societies" (March 2016), which described a conceptual model of the competences that students need to acquire if they are to participate effectively in a culture of democracy and live peacefully with others in culturally diverse democratic societies. These competences should be adapted for use in primary and secondary schools, higher education institutions and vocational training institutions across Europe and be incorporated into national curricula [17].

In June 2017, the Committee on Education and Culture of the Council of Europe held a conference entitled "Teaching Intercultural Dialogue - Living Together in Europe". The Working Group of the Committee on Education and Culture prepared a report on the outcome of the conference, chaired by Roseline Moreau, to highlight the crucial role that education plays in facilitating intercultural dialogue through its academic dimension. The fourth section of the report "Teaching Intercultural Dialogue and Competence" focuses on the analysis of the interconnections between culture, democracy and intercultural dialogue in intercultural societies [18].

In the context of our analysis, it is important to draw attention to the Copenhagen Conference (April, 2018), "Democratic culture - from words to action", organized by the Department of Education 
Policy in the context of the Danish Presidency of the Committee of Ministers. The conference resulted in the approval of "The Reference Framework of Competences for Democratic Culture (RFCDC)" and officially launched a new project "Council of Europe Educational Policy Advisory Network". This was accompanied by the decision of the 25th session of the Permanent Conference of Ministers of Education to restore the former network of coordinators of education on democratic citizenship and human rights.

Council of Europe Educational Policy Advisory Network will promote effective reforms in the 50 member states of the European Cultural Convention on Education for Democracy and Human Rights, in particular: promoting the integration of RFCDC into the educational systems of European member states; sharing experiences and discussing methods to improve cooperation and effectiveness of the RFCDC integration at all levels (national, regional and local); support for the strengthening of a safe learning environment where respect for diversity and freedom of expression without fear contributes to the development of democratic school governance as a foundation for effective education [19].

The Reference Framework of Competences for Democratic Culture has been an important start for many projects that are taking place now. The document consists of three volumes. The first volume contains a competency model created by an interdisciplinary team of international experts after extensive research and consultation. The third section of the first volume of this document is entitled "The Need for a Culture of Democracy and Intercultural Dialogue", which states that democratic and intercultural competences are not acquired automatically; they should be studied and practiced. Education is in a position to guide and support students in this, and thereby empower them. They have the necessary opportunities to become active and autonomous participants in democracy, intercultural dialogue and in community.

The second volume contains definitions that describe the learning objectives and outcomes for each competency. This should help educators create learning situations where one can observe the behavior of a student regarding a particular competence. The third volume provides tips on how to use the competency model in six educational contexts.

The framework helps the educational plan to achieve this goal - to enable all students to become autonomous and respectful democratic citizens, providing them with the competencies necessary for democracy and intercultural dialogue [19].

The results of the RFCDC were used to develop the "Strategy for the Implementation of the Competence Framework for a Culture of Democracy" and the project "Collecting Effective Practices for Teaching Controversial Issues in Schools" [20].

The idea and main points of the RFCDC have been tested in Ukraine during a series of activities under the support of Democratic School for Educational Reform Program in Ukraine during 2018, namely: during the training "Developing Civic and Social Competences in the Teacher Training System in Ukraine" (Kyiv, January 20-25, 2018), International Colloquium "Standards of the New Ukrainian School: Competence Potential. Reboot" (Kyiv, April 25-27, in collaboration with the European Education Fund), training for trainers of the Democratic School program (Kyiv, August 1418, 2018), training "Developing and evaluating civic competence in the new Ukrainian School: A Framework for Competencies for a Culture of Democracy" for representatives of postgraduate education institutions (Kyiv, November 20-21, 2018) [20].

Conclusions. The main areas of cooperation of Ukraine with the Council of Europe in the current context are: reforming of current and implementing new legislation in accordance with Council of Europe standards based on the rule of law and human rights; building a tolerant, democratic society based on European standards, in particular as regards social and minority rights, equal rights for women and men, protection of children, etc.

Based on the analysis of European normative documents and recommendations, we can conclude that: the requirement of establishing intercultural dialogue and ensuring effective intercultural interaction is an urgent requirement; mastery of intercultural competence is interpreted as the necessary competence of professionals who perform their duties directly in the country and those involved internationally.

In response to the challenges facing the world today the European countries, international organizations, associations, unions, numerous consultations are being held and numerous documents and recommendations are being adopted to seek and implement new approaches to foster intercultural dialogue. Intercultural competence is interpreted in modern conditions as one of the key competences required for human realization in the multicultural diversity of the modern world, and the formation of intercultural competence of specialists - as a necessary condition for the success in a multicultural environment.

Ukraine is on the path to integration into Europe and as a party responsible as a member of the Council of Europe is obliged to comply with the requirements and take into account the recommendations 
in accordance with the regulatory documents. Therefore, Ukraine needs to start active work on launching curricula for intercultural education in secondary and higher education institutions.

\section{REFERENCES}

1. Постійне представництво України при Раді Європи [Електронний ресурс]: Web-caйт. Співробітництво між Україною та Радою Свропи. Режим доступу: https://coe.mfa.gov.ua/ua/ukrainecoe/cooperation (дата звернення 3.09.2019). - Назва з екрана.

2. Council of Europe. European Cultural Convention (Paris, 1954). Режим доступу: https://www.coe.int/en/web/cultureand-heritage/european-cultural-convention (дата звернення 4.09.2019). - Назва з екрана.

3. Council of Europe. Vienna Declaration. Режим доступу: https://search.coe.int/cm/Pages/result_details.aspx?Object $\mathrm{Id}=0900001680536 \mathrm{c} 83$ (дата звернення 4.09.2019). - Назва з екрана.

4. Верховна Рада України. Законодавство України. Рамкова конвенція про захист національних меншин - Режим доступу: https://zakon.rada.gov.ua/laws/show/995_055 (дата звернення 1.09.2019). Назва з екрана.

5. Кобзін Д. О., Шейко Р. В., Мартиненко О. А., Белоусов Ю.Л. Ксенофобія в контексті поліетнічності українського суспільства. Результати соціологічного дослідження. - Харків, 2008. - 43 с.

6. Міжкультурна освіта державного службовця в контексті європейських стандартів: навч.-метод. матеріали / Н. Б. Ларіна, О. М. Руденко; уклад. Г. І. Андрейчик. - К. : НАДУ, 2013. - 68 с.

7. Irina Sikorskaya. Intercultural education policies across Europe as responses to cultural diversity (2006-2016) Dipartimento di Scienze Politiche, Sociali e della Comunicazione UNIVERSITÀ DEGLI STUDI DI SALERNO 2017. Режим доступу: http://www.unisa.it/uploads/12828/2017_cse_wp_4._irina_sykorskaya_intercultural_educat ion_policies_across_europe_as_responses_to_cultural_diversity.pdf (дата звернення 1.09.2019). - Назва з екрана.

8. Opening Conference for the 50th Anniversary of the European Cultural Convention. Council of Europe.Режим доступу: https://www.coe.int/t/dg4/culturalconvention/Declaration_en.asp (дата звернення 5.09.2019). - Назва з екрана.

9. Council of Europe. The Third Summit of Heads of State and Government of the Council of Europe. Режим доступу: https://www.coe.int/t/dcr/summit/20050517_decl_varsovie_EN.asp (дата звернення 7.09.2019). - Назва з екрана.

10. Council of Europe. Faro Declaration on the Council of Europe's Strategy for Developing Intercultural Dialogue. - Режим доступу: https://search.coe.int/cm/Pages/result_details.aspx?ObjectID=09000016805d91a9 (дата звернення 7.09.2019). - Назва з екрана.

11. Верховна Рада України. Законодавство України. Конвенція про охорону та заохочення розмаїття форм культурного самовираження (укр/рос). - Режим доступу https://zakon.rada.gov.ua/laws/show/952_008 (дата звернення 8.09.2019). - Назва з екрана.

12. Верховна Рада України. Законодавство України. Рекомендація 2006/962/ЄС Європейського Парламенту та Ради (СС) "Про основні компетенції для навчання протягом усього життя" від 18 грудня 2006 року. Режим доступу: https://zakon.rada.gov.ua/laws/show/994_975 (дата звернення 16.09.2019). - Назва з екрана.

13. Рада Європи.Комітет міністрів. (2010) Біла книга з міжкультурного діалогу «Жити разом у рівності й гідності» Міністерство культури і туризму України, переклад з англійської. ЦР «Демократія через культуру», Київ, Україна. Поліграфічна фірма «Оранта». - 48 ст.

14. Данишенко О.С. Міжкультурна компетентність як вимога часу в європейському вимірі державного управління. Електронний журнал «Державне управління: удосконалення та розвиток» № 6, 2014. Режим доступу: http://www.dy.nayka.com.ua/?op=1\&z=939 (дата звернення 16.09.2019). - Назва з екрана.

15. Council of Europe. The Report of the Group of Eminent Persons of the Council of Europe. Living together. Combining diversity and freedom in 21st-century Europe, 2011. - Режим доступу: https://rm.coe.int/16806b97c5 (дата звернення 21.09.2019). - Назва з екрана.

16. The European Parliament. Committee on Culture and Education. Motion for a European Parliament Resolution on the role of intercultural dialogue, cultural diversity and education in promoting EU fundamental values. - Режим доступу: http://www.europarl.europa.eu/doceo/document/A-8-20150373_EN.html?redirect (дата звернення 21.09.2019). - Назва з екрана.

17. Council of Europe. Competences for Democratic Culture. Living together as equals in culturally diverse democratic societies. - Режим доступу: https://rm.coe.int/16806сcс0с (дата звернення 1.09.2019). - Назва з екрана.

18. Conference of INGOs of the Council of Europe. Education and Culture Committee. "Educating on Intercultural Dialogue - Living Together in Europe". - Режим доступу: https://rm.coe.int/090000168076c3e1 (дата звернення 26.09.2019). - Назва з екрана.

19. Council of Europe. Copenhagen Conference "Democratic Culture - from words to action". The Reference Framework of Competences for Democratic Culture (RFCDC). Режим доступу: https://www.coe.int/en/web/education/competen ces-for-democratic-culture (дата звернення 3.09.2019). - Назва з екрана.

20. Рада Європи. Рамка компетентностей для культури демократії. Том 1. 2018. - Режим доступу: https://rm.coe.int/rf-cdc-vol-1-/1680966746 (дата звернення 3.09.2019). - Назва з екрана. 